\title{
Application of Diaminium Iodides in Binary Ionic Liquid Electrolytes for Dye-Sensitized Solar Cells
}

\author{
Yanzhen Yang, ${ }^{1}$ Renjie Sun, ${ }^{2,3}$ Chengwu Shi, ${ }^{2,3}$ Yucheng Wu, ${ }^{1}$ and Mei $\mathrm{Xia}^{2,3}$ \\ ${ }^{1}$ School of Materials Science and Engineering, Hefei University of Technology, Hefei 230009, China \\ ${ }^{2}$ School of Chemical Engineering, Hefei University of Technology, Hefei 230009, China \\ ${ }^{3}$ Key Lab of Novel Thin Film Solar Cells, Chinese Academy of Sciences, Hefei 230031, China \\ Correspondence should be addressed to Chengwu Shi, shicw506@gmail.com and Yucheng Wu, ycwu@hfut.edu.cn \\ Received 27 January 2011; Revised 24 April 2011; Accepted 2 May 2011 \\ Academic Editor: Gion Calzaferri \\ Copyright (C) 2011 Yanzhen Yang et al. This is an open access article distributed under the Creative Commons Attribution License, \\ which permits unrestricted use, distribution, and reproduction in any medium, provided the original work is properly cited. \\ $\mathrm{N}$-(2-hydroxyethyl)ethylenediaminium iodides (HEEDAIs) and N-(2-hydroxyethyl)piperazinium iodides (HEPIs) were synthe- \\ sized, and their thermal properties were analysed. The influence of HEEDAI and HEPI on $\mathrm{I}_{3}^{-} / \mathrm{I}^{-}$redox behavior in binary ionic \\ liquid was investigated. The result revealed that HEEDAI can suppress the recombination between $\mathrm{I}_{3}{ }^{-}$and the injected electrons \\ in $\mathrm{TiO}_{2}$ conduction band and be used as the alternative of 4-tert-butylpyridine in the electrolyte of dye-sensitized solar cells. \\ The electrolyte $\mathrm{C}, 0.15 \mathrm{~mol} \cdot \mathrm{L}^{-1} \mathrm{I}_{2}$, HEEDAI and MPII with mass ratio of $1: 4$, gave the short-circuit photocurrent density of \\ $9.36 \mathrm{~mA} \cdot \mathrm{cm}^{-2}$, open-circuit photovoltage of $0.67 \mathrm{~V}$, fill factor of 0.52 , and the corresponding photoelectric conversion efficiency \\ of $3.24 \%$ at the illumination (air mass $1.5,100 \mathrm{~mW} \cdot \mathrm{cm}^{-2}$, active area $0.25 \mathrm{~cm}^{2}$ ).
}

\section{Introduction}

Dye-sensitized solar cells (DSCs) have been extensively studied due to their high light-to-electric energy conversion yield. The electrolyte is one of the critical components of DSCs and has the remarkable effect on the stability under long-term thermal and light-soaking dual stresses [1-3]. Various functionalized imidazolium iodide salts [4-9] and the additives containing basic $\mathrm{N}$ atoms, such as pyridine $[10,11]$, benzimidazole [12, 13], aminotriazole [14], have been evaluated as electrolytes in DSCs with some success. Compared with the imidazolium iodides and pyridine derivatives, diaminium iodides serve as the iodide resource of $\mathrm{I}_{3}{ }^{-} / \mathrm{I}^{-}$redox couples and contain basic $\mathrm{N}$ atoms. However, their application in the electrolytes of DSCs has not been reported.

In this paper, $\mathrm{N}$-(2-hydroxyethyl)ethylenediaminium iodides (HEEDAI) and N-(2-hydroxyethyl)piperazinium iodides (HEPI) were synthesized, and their thermal properties were characterized by the thermogravimetric analysis and differential scanning calorimeter. The influence of HEEDAI and HEPI on $\mathrm{I}_{3}{ }^{-} / \mathrm{I}^{-}$redox behavior in binary ionic liquid was investigated by cyclic voltammetry using a Pt disk ultramicroelectrode and electrochemical impedance spec- troscopy. And the photovoltaic performances of the corresponding DSCs were measured.

\section{Experimental}

2.1. Materials. All chemical reagents were commercially available and used without further purification. 1-methyl-3propylimidazolium iodide (MPII) was synthesized according to our previous report [15].

2.2. Measurement. The melting and freezing points of HEEDAI and HEPI were characterized by differential scanning calorimeter using a Thermal Analysis DSC821 with heating rate at $10^{\circ} \mathrm{C} \cdot \mathrm{min}^{-1}$, under a nitrogen flow rate of about $30 \mathrm{~mL} \cdot \mathrm{min}^{-1}$. And their thermal stability was analyzed on a TG209F3 Tarsws NETZSCH thermogravimetric balance at a heating rate of $10^{\circ} \mathrm{C} \cdot \mathrm{min}^{-1}$ under nitrogen atmosphere.

The measurements of cyclic voltammetry (CV) and electrochemical impedance spectroscopy (EIS) for binary ionic liquid and the fabrication of DSCs were similar to our previous reports [15-18]. Briefly, The CV measurement was achieved by using an electrochemical workstation (CHI660B). The working electrode was a $5.0 \mu \mathrm{m}$ radius $\mathrm{Pt}$ 


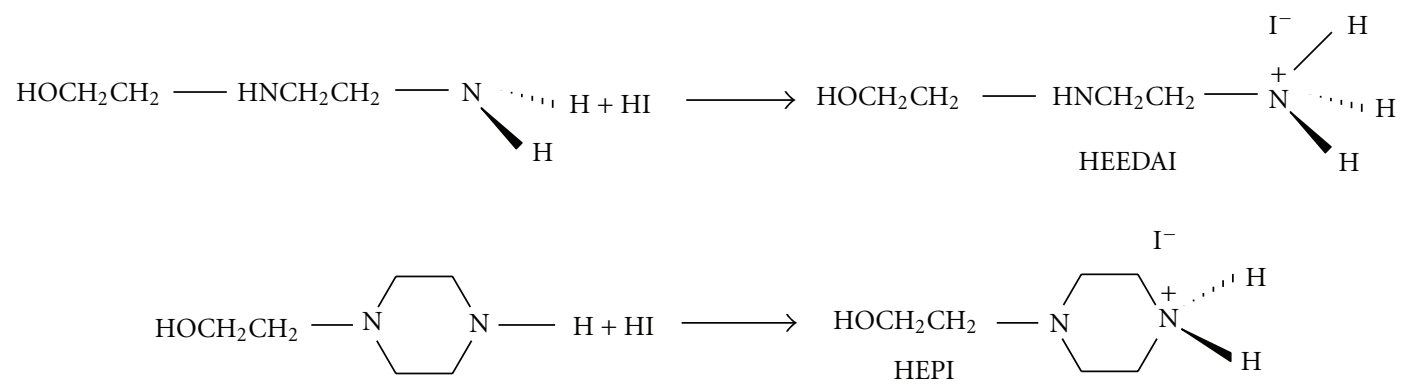

Scheme 1: The synthesis reaction of HEEDAI and HEPI.

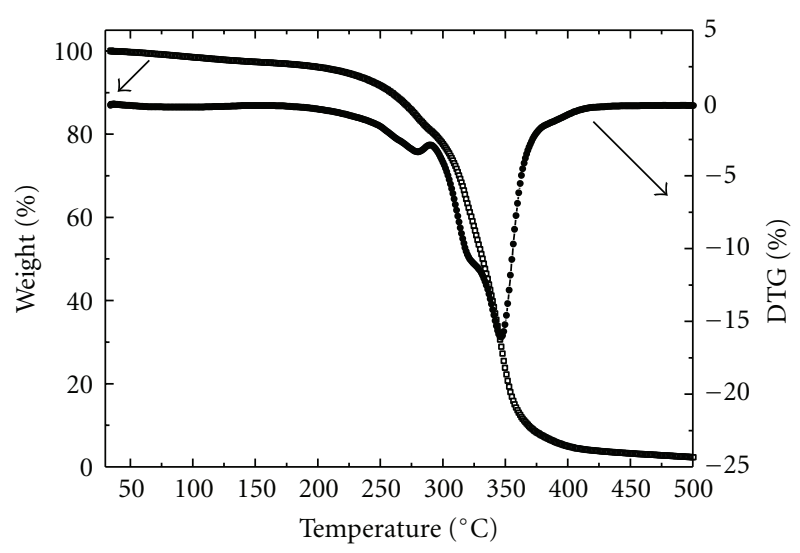

Figure 1: Thermogravimetric analysis curves of HEEDAI.

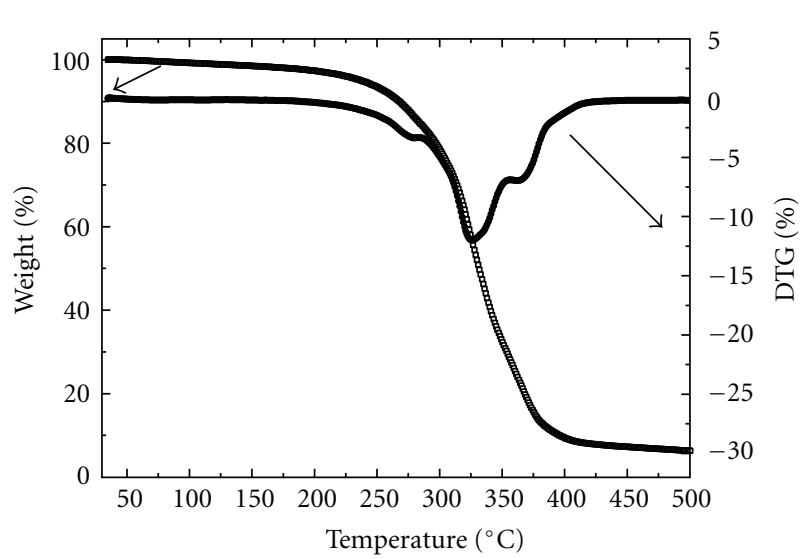

FIgURE 2: Thermogravimetric analysis curves of HEPI.

disk ultramicroelectrode (CHI107); the auxiliary electrode and the reference electrode were a $1.0 \mathrm{~mm}$ radius $\mathrm{Pt}$ disk electrode (CHI102). A slow scan rate at $5 \mathrm{mV} \cdot \mathrm{s}^{-1}$ was used to obtain steady-state current-voltage curves. The EIS measurement was carried out with a two-platinum-blackelectrode conductance cell (DJS-1C, REX, cell constant is 0.974). After every EIS measurement, the conductance cell was washed with anhydrous ethanol and immersed in distilled water overnight. EIS spectra were obtained by applying sinusoidal perturbations of $\pm 10 \mathrm{mV}$ over the bias $0 \mathrm{~V}$ at frequencies from 1 to $10 \mathrm{kHz}$. The $\mathrm{TiO}_{2}$ paste was printed on transparent conducting glass sheets (TEC-8, LOF)

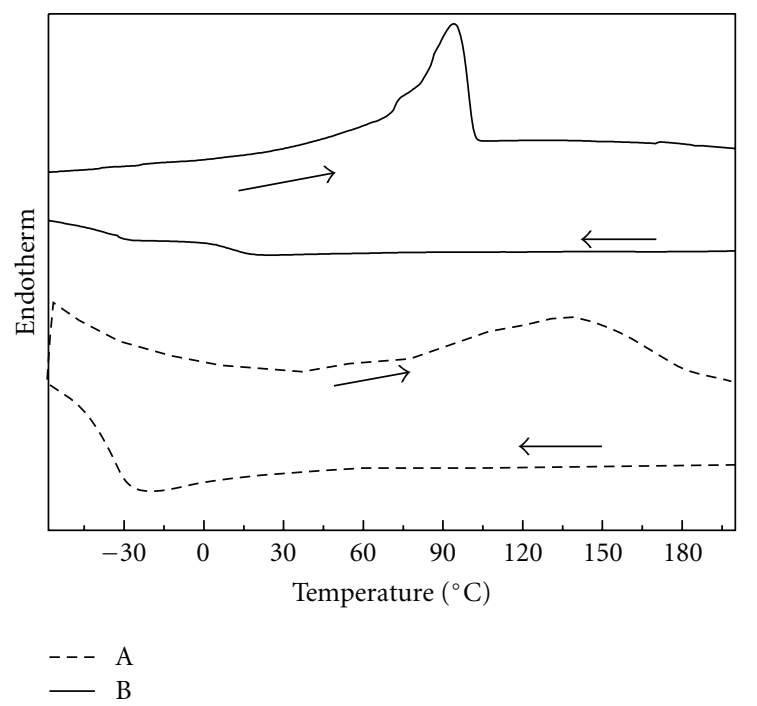

FIgure 3: Differential scanning calorimeter curves of (A) HEEDAI and (B) HEPI.

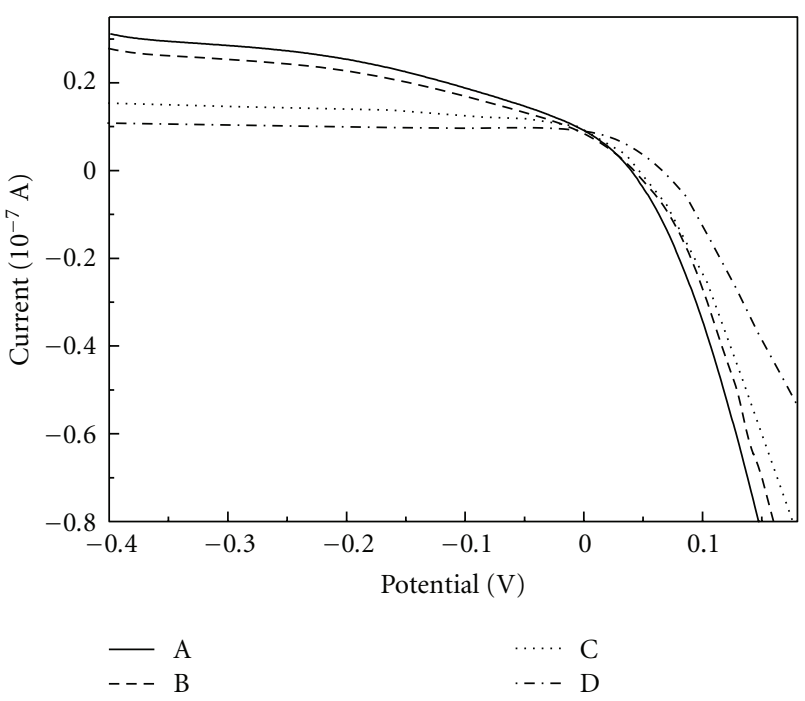

FIgURE 4: Steady-state voltammograms of solutions $\mathrm{A} \sim \mathrm{D}$ at $25^{\circ} \mathrm{C}$. Solution component: (A) m(HEEDAI) $: \mathrm{m}(\mathrm{MPII})=1: 9$; (B) $\mathrm{m}($ HEPI $): \mathrm{m}($ MPII $)=1: 9$; (C) $\mathrm{m}($ HEEDAI $): \mathrm{m}($ MPII $)=1: 4$; (D) $\mathrm{m}($ HEEDAI $): \mathrm{m}($ MPII $)=1: 1$, and $0.15 \mathrm{~mol} \cdot \mathrm{L}^{-1} \mathrm{I}_{2}$. 


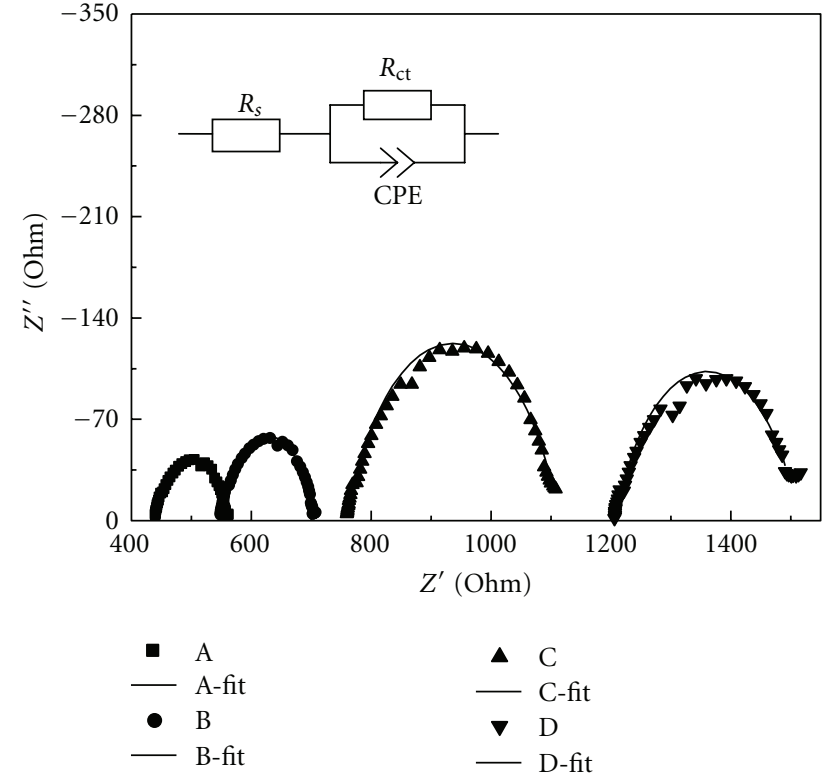

FIGURE 5: EIS and its equivalent circuit of solutions $\mathrm{A} \sim \mathrm{D}$ at $25^{\circ} \mathrm{C}$. Solution component: (A) $\mathrm{m}($ HEEDAI $): \mathrm{m}(\mathrm{MPII})=1: 9 ;(\mathrm{B})$ $\mathrm{m}$ (HEPI) $: \mathrm{m}$ (MPII) $=1: 9$; (C) $\mathrm{m}$ (HEEDAI) $: \mathrm{m}($ MPII $)=1: 4$; (D) $\mathrm{m}($ HEEDAI $): \mathrm{m}($ MPII $)=1: 1$, and $0.15 \mathrm{~mol} \cdot \mathrm{L}^{-1} \mathrm{I}_{2}$.

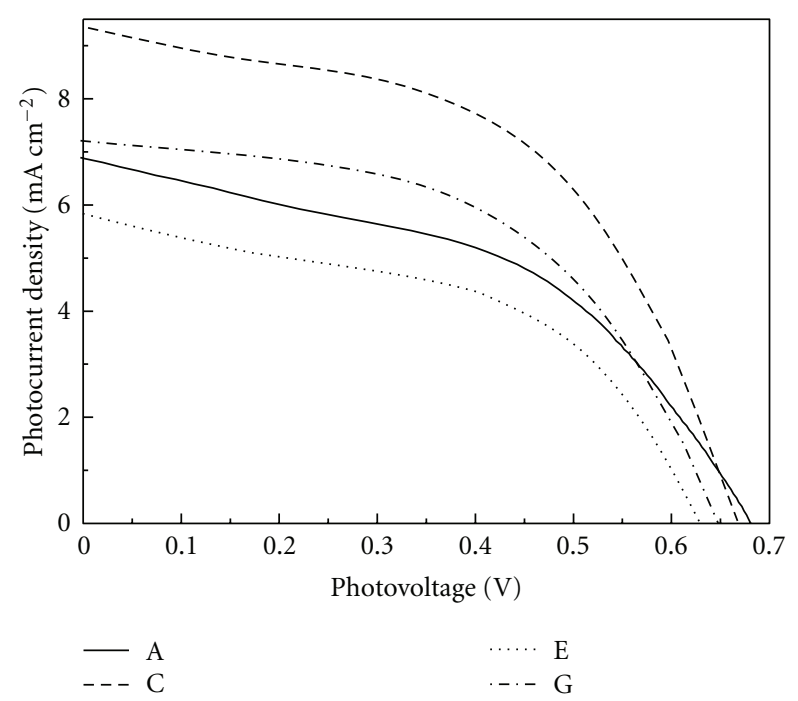

FIGURE 6: Photocurrent-photovoltage characteristics of DSCs with electrolytes $A \sim G$. Component of electrolytes $A \sim G$ is the same as that in Table 3.

and sintered in air at $450^{\circ} \mathrm{C}$ for $30 \mathrm{~min}$. The film was $\sim 10 \mu \mathrm{m}$ thick, which was determined by profilometer (XP-2, AMBIOS Technology Inc. USA). A $4 \mu \mathrm{m}$ thick light scattering layer was used. After cooling to $80^{\circ} \mathrm{C}$, the $\mathrm{TiO}_{2}$ films were immersed in anhydrous ethanol solution with $5.0 \times 10^{-4} \mathrm{~mol} \cdot \mathrm{L}^{-1} \quad$ cis-dithiocyanate- $\mathrm{N}, \mathrm{N}^{\prime}$-bis-(4-carboxylate-4-tetrabutylammonium carboxylate-2,2'-bipyridine) ruthenium (II) (N719) overnight. The excess of N719 dye in $\mathrm{TiO}_{2}$ films was rinsed off with anhydrous ethanol before assembly. The counterelectrode was platinized by spraying
Table 1: Apparent diffusion coefficient $\left(D_{\text {app }}\right)$ of $\mathrm{I}_{3}{ }^{-}$in solutions $\mathrm{A} \sim \mathrm{D}$.

\begin{tabular}{lc}
\hline Solution & $10^{-7} D_{\text {app }}\left(\mathrm{I}_{3}^{-}\right) /\left(\mathrm{cm}^{2} \cdot \mathrm{s}^{-1}\right)$ \\
\hline (A) $\mathrm{m}($ HEEDAI $): \mathrm{m}($ MPII $)=1: 9$ & 5.0 \\
(B) $\mathrm{m}($ HEPI $): \mathrm{m}($ MPII $)=1: 9$ & 4.4 \\
(C) $\mathrm{m}($ HEEDAI $): \mathrm{m}($ MPII $)=1: 4$ & 2.5 \\
(D) $\mathrm{m}($ HEEDAI $): \mathrm{m}($ MPII $)=1: 1$ & 1.8 \\
\hline
\end{tabular}

The other component of solutions A D was $0.15 \mathrm{~mol} \cdot \mathrm{L}^{-1} \mathrm{I}_{2}$.

$\mathrm{H}_{2} \mathrm{PtCl}_{6}$ solution to transparent conducting glass and fired in air at $410^{\circ} \mathrm{C}$ for $20 \mathrm{~min}$. Then, it was placed directly on the top of the dye-sensitized $\mathrm{TiO}_{2}$ films. The gap between the two electrodes was sealed by thermal adhesive (Surlyn, Dupont). The electrolyte was filled from a hole made on the counter electrode, and the hole was later sealed by a cover glass and thermal adhesive films. The active area of DSCs was $0.25 \mathrm{~cm}^{2}$. The photovoltaic performances of DSCs were measured with a solar simulator (Class AAA, Oriel, Newport, USA, Air Mass $1.5,100 \mathrm{~mW} \cdot \mathrm{cm}^{-2}$ ) and a Keithley 2420 source meter controlled by Testpoint software. The irradiation intensity was calibrated with standard crystalline silicon solar cell (Oriel, Newport, USA).

2.3. Synthesis Procedure. HEEDAI and HEPI were synthesized by the neutralization reaction of $\mathrm{N}$-(2-hydroxyethyl)ethylenediamine/N-(2-hydroxyethyl)piperazine and $\mathrm{HI}$ using the stoichiometric amounts of reactants (Scheme 1).

$\mathrm{N}$-(2-hydroxyethyl)ethylenediamine $(45.00 \mathrm{~g}, 0.43 \mathrm{~mol}$, HEEDA) was dissolved in the equal weight of deionized water. Then hydriodic acid (122.81 g, $0.43 \mathrm{~mol} \mathrm{HI}, 45 \%$ mass fraction) was slowly dropped to the above solution with magnetic stirring at room temperature. Subsequently, the reaction mixture was stirred for $30 \mathrm{~min}$, and the deionized water was removed by rotary evaporator at $90^{\circ} \mathrm{C}$ and dried in vacuum at $80^{\circ} \mathrm{C}$ for $6 \mathrm{~h}$. A red viscous liquid, HEEDAI, was obtained. Yield: $94.26 \mathrm{~g}(94 \%)$.

The synthesis of HEPI was similar to that of HEEDAI. A white solid, HEPI, was obtained with the reaction of $\mathrm{N}$-(2-hydroxyethyl)piperazine ( $45.54 \mathrm{~g}, 0.35 \mathrm{~mol}, \mathrm{HEP})$ and hydroiodic acid (99.50 g, $0.35 \mathrm{~mol} \mathrm{HI}, 45 \%$ mass fraction). Yield: $86.70 \mathrm{~g}(96 \%)$.

\section{Results and Discussion}

3.1. Thermal Analysis of HEEDAI and HEPI. Figures 1 and 2 showed thermogravimetric analysis curves of HEEDAI and HEPI. The decomposition temperatures of HEEDAI and HEPI were $345^{\circ} \mathrm{C}$ and $325^{\circ} \mathrm{C}$. This result revealed that the thermal stability of HEEDAI was superior to that of HEPI. Because the $p K_{b 1}$ of HEEDA and HEP were 4.4 and 4.8, respectively [19], the basicity of HEEDA was more intense than that of HEP, and the $\mathrm{N}-\mathrm{H}$ bond energy in the resulting iodide salt, HEEDAI, was higher than that in HEPI. The N$\mathrm{H}$ bond break of HEEDAI required higher decomposition temperature than HEPI. 
TABLE 2: Parameters obtained by fitting the experimental spectra with the equivalent circuit.

\begin{tabular}{|c|c|c|c|c|}
\hline Solution & $R_{\mathrm{s}} / \mathrm{Ohm}$ & $R_{\mathrm{ct}} / \mathrm{Ohm}$ & $Y_{0} / \mu \mathrm{Fs}^{n-1}$ & $n$ \\
\hline (A) $m($ HEEDAI $): m($ MPII $)=1: 9$ & 440 & 120 & 33 & 0.8 \\
\hline (B) $m($ HEPI $): m($ MPII $)=1: 9$ & 549 & 156 & 25 & 0.8 \\
\hline (C) $\mathrm{m}($ HEEDAI $): \mathrm{m}$ (MPII) $=1: 4$ & 769 & 340 & 32 & 0.8 \\
\hline (D) $\mathrm{m}($ HEEDAI $): \mathrm{m}(\mathrm{MPII})=1: 1$ & 1209 & 303 & 46 & 0.8 \\
\hline
\end{tabular}

Component of solutions A D was the same as that in Figure 5.

$R_{\mathrm{s}}$ : serial resistance (resistance of solutions); $R_{\mathrm{ct}}$ : charge-transfer resistance; CPE: constant phase element; $Y_{0}$ : constant phase angle element; $n$ : a constant ranging from $0 \leq n \leq 1$.

TABLe 3: Photovoltaic performance of DSCs with electrolytes A G.

\begin{tabular}{|c|c|c|c|c|}
\hline Electrolyte & $J_{\mathrm{sc}} /\left(\mathrm{mA} \cdot \mathrm{cm}^{-2}\right)$ & $V_{\mathrm{oc}} / \mathrm{V}$ & $F F$ & $\eta(\%)$ \\
\hline (A) $\mathrm{m}(\mathrm{HEEDAI}): \mathrm{m}(\mathrm{MPII})=1: 9$ Without TBP & 6.88 & 0.68 & 0.46 & 2.16 \\
\hline (B) $\mathrm{m}(\mathrm{HEEDAI}): \mathrm{m}(\mathrm{MPII})=1: 9,0.5 \mathrm{~mol} \cdot \mathrm{L}^{-1} \mathrm{TBP}$ & 6.64 & 0.69 & 0.45 & 2.06 \\
\hline (C) $\mathrm{m}(\mathrm{HEEDAI}): \mathrm{m}(\mathrm{MPII})=1: 4$ Without TBP & 9.36 & 0.67 & 0.52 & 3.24 \\
\hline (D) $\mathrm{m}(\mathrm{HEEDAI}): \mathrm{m}(\mathrm{MPII})=1: 4,0.5 \mathrm{~mol} \cdot \mathrm{L}^{-1} \mathrm{TBP}$ & 8.96 & 0.66 & 0.52 & 3.06 \\
\hline (E) $\mathrm{m}(\mathrm{HEEDAI}): \mathrm{m}(\mathrm{MPII})=1: 1$ Without TBP & 5.76 & 0.63 & 0.50 & 1.80 \\
\hline (F) $\mathrm{m}(\mathrm{HEEDAI}): \mathrm{m}(\mathrm{MPII})=1: 1,0.5 \mathrm{~mol} \cdot \mathrm{L}^{-1} \mathrm{TBP}$ & 5.68 & 0.64 & 0.48 & 1.74 \\
\hline (G) $\mathrm{m}($ HEPI $): \mathrm{m}(\mathrm{MPII})=1: 9$ Without TBP & 7.20 & 0.65 & 0.53 & 2.44 \\
\hline
\end{tabular}

The electrolyte component of A $\sim$ G: (A) $\mathrm{m}($ HEEDAI $): \mathrm{m}($ MPII $)=1: 9 ;(B) \mathrm{m}($ HEEDAI $): \mathrm{m}(\mathrm{MPII})=1: 9,0.5 \mathrm{~mol} \cdot \mathrm{L}^{-1} \mathrm{TBP},(\mathrm{C}) \mathrm{m}(\mathrm{HEEDAI}): \mathrm{m}(\mathrm{MPII})$ $=1: 4 ;$ (D) $\mathrm{m}($ HEEDAI $): \mathrm{m}($ MPII $)=1: 4,0.5 \mathrm{~mol} \cdot \mathrm{L}^{-1} \mathrm{TBP}$ (E) $\mathrm{m}(\mathrm{HEEDAI}): \mathrm{m}(\mathrm{MPII})=1: 1 ;(\mathrm{F}) \mathrm{m}(\mathrm{HEEDAI}): \mathrm{m}(\mathrm{MPII})=1: 1,0.5 \mathrm{~mol} \cdot \mathrm{L}^{-1} \mathrm{TBP}$; and $0.15 \mathrm{~mol} \cdot \mathrm{L}^{-1} \mathrm{I}_{2} ;$ (G) $\mathrm{m}(\mathrm{HEPI}): \mathrm{m}(\mathrm{MPII})=1: 9$ and $0.15 \mathrm{~mol} \cdot \mathrm{L}^{-1} \mathrm{I}_{2}, 0.1 \mathrm{~mol} \cdot \mathrm{L}^{-1}$ LiI. Illumination: AM $1.5,100 \mathrm{mV} \cdot \mathrm{cm}^{-2}$, active areas of DSCs: $0.25 \mathrm{~cm}{ }^{2}$.

Figure 3 showed differential scanning calorimeter curves of HEEDAI and HEPI. HEEDAI had a glass transition temperature at $-28^{\circ} \mathrm{C}$, a crystallization peak followed by a broad melting transition between $-10^{\circ} \mathrm{C}$ and $170^{\circ} \mathrm{C}$. And the melting point of $\mathrm{HEPI}$ was $94^{\circ} \mathrm{C}$, while the freezing points of HEEDAI and HEPI were not observed. It was indicated that the two iodide ionic liquids were transferred from equilibrium liquid state into the metastable supercooled liquid state when refrigerated from high temperature to low temperature.

\subsection{Influence of HEEDAI and HEPI on $\mathrm{I}_{3}{ }^{-} / \mathrm{I}^{-}$Redox Behavior} in Binary Ionic Liquid. Figure 4 showed steady-state voltammograms of the solutions $\mathrm{A} \sim \mathrm{D}$ at $25^{\circ} \mathrm{C}$. Due to the large excess of $\mathrm{I}^{-}$relative to $\mathrm{I}_{3}{ }^{-}$, only the cathodic steady-state diffusion current of $\mathrm{I}_{3}{ }^{-}$was measured in solutions $\mathrm{A} \sim \mathrm{D}$ and the apparent diffusion coefficient $\left(D_{\text {app }}\right)$ of $\mathrm{I}_{3}{ }^{-}$was listed in Table 1. Compared with solution $\mathrm{A}$ and $\mathrm{B}, D_{\text {app }}$ value of $\mathrm{I}_{3}{ }^{-}$in binary ionic liquid of HEEDAI and MPII was higher than that in HEPI and MPII. This was because the molecular size of HEPI was larger than that of HEEDAI. From solutions A, C, and D, the diffusion coefficients of $\mathrm{I}_{3}{ }^{-}$increased with the increase of MPII. This was because MPII had lower macroscopic viscosity than that of HEEDAI. It was noteworthy that the diffusion coefficients of $\mathrm{I}_{3}{ }^{-}$in binary ionic liquid of HEEDAI and MPII, the mass ratio of $1: 4$ and $1: 9$, were higher than pure MPII solution $(1.88 \times$ $\left.10^{-7} \mathrm{~cm}^{2} \cdot \mathrm{s}^{-1}\right)[20]$.

Figure 5 showed the EIS spectra of the solutions $A \sim D$ at $25^{\circ} \mathrm{C}$. Experimental data were represented by symbols and the solid lines corresponded to the fit using the equivalent circuit [15-18]. The parameters obtained by fitting the experimental spectra with the equivalent circuit were listed in Table 2. With the increase of HEEDAI, the viscosity of solution increased, and $R_{\mathrm{s}}$ and $R_{\mathrm{ct}}$ increased. This result was consistent with the diffusion coefficient of $\mathrm{I}_{3}{ }^{-}$in binary ionic liquid of HEEDAI and MPII. Moreover, the values of $R_{\mathrm{s}}$ and $R_{\mathrm{ct}}$ in binary ionic liquid of HEPI and MPII were higher than that in binary ionic liquid of HEEDAI with MPII.

3.3. Photovoltaic Performances of DSCs. Table 3 and Figure 6 showed the photovoltaic performance of DSCs. The electrolyte $\mathrm{C}$ gave the short-circuit photocurrent density $\left(J_{\mathrm{sc}}\right)$ of $9.36 \mathrm{~mA} \cdot \mathrm{cm}^{-2}$, open-circuit photovoltage $\left(V_{\mathrm{oc}}\right)$ of $0.67 \mathrm{~V}$, fill factor $(F F)$ of 0.52 , and yielded an overall photoelectric conversion efficiency $(\eta)$ of $3.24 \%$. From Table 3, it was interesting that the addition of $0.50 \mathrm{~mol} \cdot \mathrm{L}^{-1} 4$-tert-butylpyridine (TBP) in binary ionic liquid of HEEDAI and MPII cannot improve the photoelectric conversion efficiency of DSCs. This was because HEEDAI, similar to TBP, contains the basic $\mathrm{N}$ atoms. These $\mathrm{N}$ atoms can be adsorbed on the $\mathrm{TiO}_{2}$ surface to suppress the recombination between $\mathrm{I}_{3}{ }^{-}$and the injected electrons in $\mathrm{TiO}_{2}$ conduction band. Therefore, HEEDAI can be used as the alternative of TBP in the electrolyte of DSCs and has lower volatility than TBP.

Compared with electrolytes $\mathrm{C}$ and $\mathrm{A}$, the short-circuit photocurrent density $\left(J_{s c}\right)$ and fill factor $(F F)$ of electrolyte $\mathrm{C}$ were higher than those of electrolytes A. This result was because the HEEDAI content in electrolyte $C$ was higher than electrolyte $\mathrm{A}$, which can suppress the recombination between $\mathrm{I}_{3}{ }^{-}$and the injected electrons in $\mathrm{TiO}_{2}$ conduction band. Compared with electrolytes $\mathrm{E}$ and $\mathrm{C}$, the short-circuit photocurrent density $\left(J_{s c}\right)$ and fill factor $(F F)$ of electrolyte $\mathrm{E}$ were lower than those of electrolyte $\mathrm{C}$. This result were because the diffusion coefficient of $\mathrm{I}_{3}{ }^{-}$in electrolyte $\mathrm{E}$ is lower those electrolyte C. Moreover, there were no obvious differences of photoelectric conversion efficiency between electrolytes A and G. 


\section{Conclusion}

HEEDAI and HEPI were synthesized, and their thermal properties were characterized by the thermogravimetric analysis and differential scanning calorimeter. The influence of HEEDAI and HEPI on $\mathrm{I}_{3}{ }^{-} / \mathrm{I}^{-}$redox behavior in binary ionic liquid was investigated by cyclic voltammetry using a Pt disk ultramicroelectrode and electrochemical impedance spectroscopy. It was found that HEEDAI had a glass transition temperature at $-28^{\circ} \mathrm{C}$, the melting point of HEPI was $94^{\circ} \mathrm{C}$, and the freezing points of HEEDAI and HEPI were not observed. And HEEDAI can suppress the recombination between $\mathrm{I}_{3}{ }^{-}$and the injected electrons in $\mathrm{TiO}_{2}$ conduction band and be used as the alternative of TBP in the electrolyte of DSCs. Moreover, The electrolyte C, $0.15 \mathrm{~mol} \cdot \mathrm{L}^{-1} \mathrm{I}_{2}$, HEEDAI and MPII with mass ratio of $1: 4$, gave the shortcircuit photocurrent density of $9.36 \mathrm{~mA} \cdot \mathrm{cm}^{-2}$, open-circuit photovoltage of $0.67 \mathrm{~V}$, fill factor of 0.52 , and the corresponding photoelectric conversion efficiency of $3.24 \%$.

\section{Acknowledgment}

This work is financially supported by the College Natural Science Foundation of Anhui Province (KJ2010A266), Anhui Province Science and Technology Plan Project of China (2010AKND0794), and the National High Technology Research and Development Program of China (2009AA 050603).

\section{References}

[1] H. J. Snaith and L. Schmidt-Mende, "Advances in liquidelectrolyte and solid-state dye-sensitized solar cells," Advanced Materials, vol. 19, no. 20, pp. 3187-3200, 2007.

[2] M. Gorlov and L. Kloo, "Ionic liquid electrolytes for dyesensitized solar cells," Dalton Transactions, no. 20, pp. 26552666, 2008.

[3] S. M. Zakeeruddin and M. Grätzel, "Solvent-free ionic liquid electrolytes for mesoscopic dye-sensitized solar cells," Advanced Functional Materials, vol. 19, no. 14, pp. 1-16, 2009.

[4] S. Kambe, S. Nakade, T. Kitamura, Y. Wada, and S. Yanagida, "Influence of the electrolytes on electron transport in mesoporous $\mathrm{TiO}_{2}$ electrolyte systems," Journal of Physical Chemistry $B$, vol. 106, no. 11, pp. 2967-2972, 2002.

[5] W. Kubo, S. Kambe, S. Nakade et al., "Photocurrent-determining processes in quasi-solid-state dye-sensitized solar cells using ionic gel electrolytes," Journal of Physical Chemistry B, vol. 107, no. 18, pp. 4374-4381, 2003.

[6] R. Kawano, H. Matsui, C. Matsuyama et al., "High performance dye-sensitized solar cells using ionic liquids as their electrolytes," Journal of Photochemistry and Photobiology A, vol. 164, no. 1-3, pp. 87-92, 2004.

[7] Z. F. Fei, D. B. Kuang, D. B. Zhao et al., "A supercooled imidazolium iodide ionic liquid as a low-viscosity electrolyte for dye-sensitized solar cells," Inorganic Chemistry, vol. 45, no. 26, pp. 10407-10409, 2006.

[8] F. Mazille, Z. F. Fei, D. B. Kuang et al., "Influence of ionic liquids bearing functional groups in dye-sensitized solar cells," Inorganic Chemistry, vol. 45, no. 4, pp. 1585-1590, 2006.
[9] Y. Q. Wang, Y. M. Sun, B. Song, and J. T. Xi, "Ionic liquid electrolytes based on 1-vinyl-3-alkylimidazolium iodides for dye-sensitized solar cells," Solar Energy Materials \& Solar Cells, vol. 92, no. 6, pp. 660-666, 2008.

[10] S. Y. Huang, G. Schlichthörl, A. J. Nozik, M. Grätzel, and A. J. Frank, "Charge recombination in dye-sensitized nanocrystalline $\mathrm{TiO}_{2}$ solar cells," Journal of Physical Chemistry B, vol. 101, no. 14, pp. 2576-2582, 1997.

[11] X. Yin, W. W. Tan, J. B. Zhang et al., "The effect mechanism of 4-ethoxy-2-methylpyridine as an electrolyte additive on the performance of dye-sensitized solar cell," Colloids and Surfaces A, vol. 326, no. 1-2, pp. 42-47, 2008.

[12] C. Zhang, J. Dai, Z. Huo et al., "Influence of 1-methylbenzimidazole interactions with $\mathrm{Li}^{+}$and $\mathrm{TiO}_{2}$ on the performance of dye-sensitized solar cells," Electrochimica Acta, vol. 53, no. 17, pp. 5503-5508, 2008.

[13] C. N. Zhang, Z. P. Huo, Y. Huang et al., "Studies of interfacial recombination in the dyed $\mathrm{TiO}_{2}$ electrode using raman spectra and electrochemical techniques," Journal of Electroanalytical Chemistry, vol. 632, no. 1-2, pp. 133-138, 2009.

[14] H. Kusama and H. Arakawa, "Influence of aminotriazole additives in electrolytic solution on dye-sensitized solar cell performance," Journal of Photochemistry and Photobiology A, vol. 164, no. 1-3, pp. 103-110, 2004.

[15] C. W. Shi, Q. Ge, S. K. Han et al., "An improved preparation of 1-methyl-3-propylimidazolium iodide and its application in dye-sensitized solar cells," Solar Energy, vol. 82, no. 5, pp. 385-388, 2008.

[16] C. Shi, Q. Ge, F. Zhou et al., "An improved preparation of 3-ethyl-1-methylimidazolium trifluoroacetate and its application in dye sensitized solar cells," Solar Energy, vol. 83, no. 1, pp. 108-112, 2009.

[17] M. Xia, C. W. Shi, R. J. Sun, M. L. Cai, and Z. k. Liu, "Solventfree synthesis of alkylbenzimidazolium iodides and their applications in dye-sensitized solar cells," Solar Energy, vol. 84, pp. 1828-1832, 2010.

[18] C. W. Shi, S. Y. Dai, K. J. Wang et al., "Influence of various cations on redox behavior of $\mathrm{I}^{-}$and $\mathrm{I}_{3}^{-}$and comparison between KI complex with 18-crown-6 and 1,2-dimethyl-3propylimidazolium iodide in dye-sensitized solar cells," Electrochimica Acta, vol. 50, no. 13, pp. 2597-2602, 2005.

[19] Q. A. Liu, Application of regeneration amines in wet flue gas desulfurization, M.S. thesis, Hefei University of Technology Master Dissertation, 2010.

[20] P. Wang, S. M. Zakeeruddin, J. E. Moser, and M. Grätzel, "A new ionic liquid electrolyte enhances the conversion efficiency of dye-sensitized solar cells," Journal of Physical Chemistry B, vol. 107, no. 48, pp. 13280-13285, 2003. 


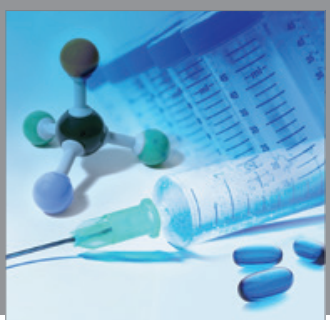

International Journal of

Medicinal Chemistry

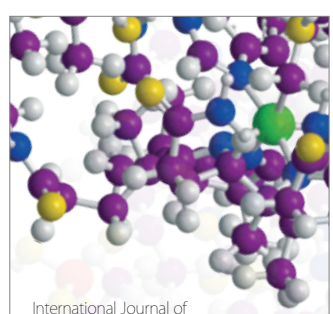

Carbohydrate Chemistry

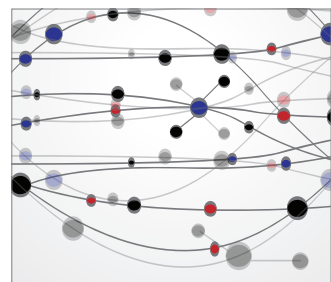

The Scientific World Journal
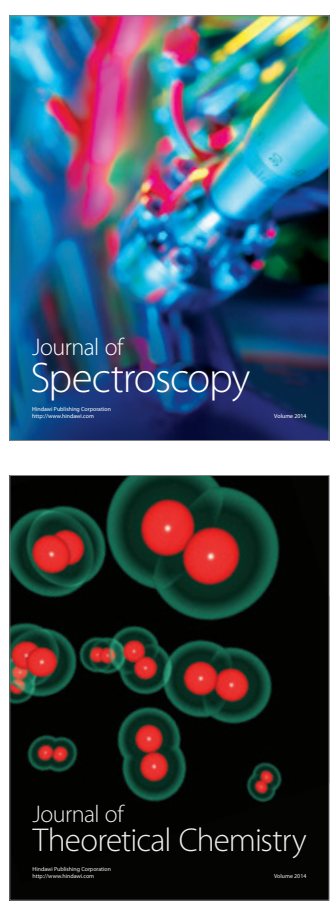
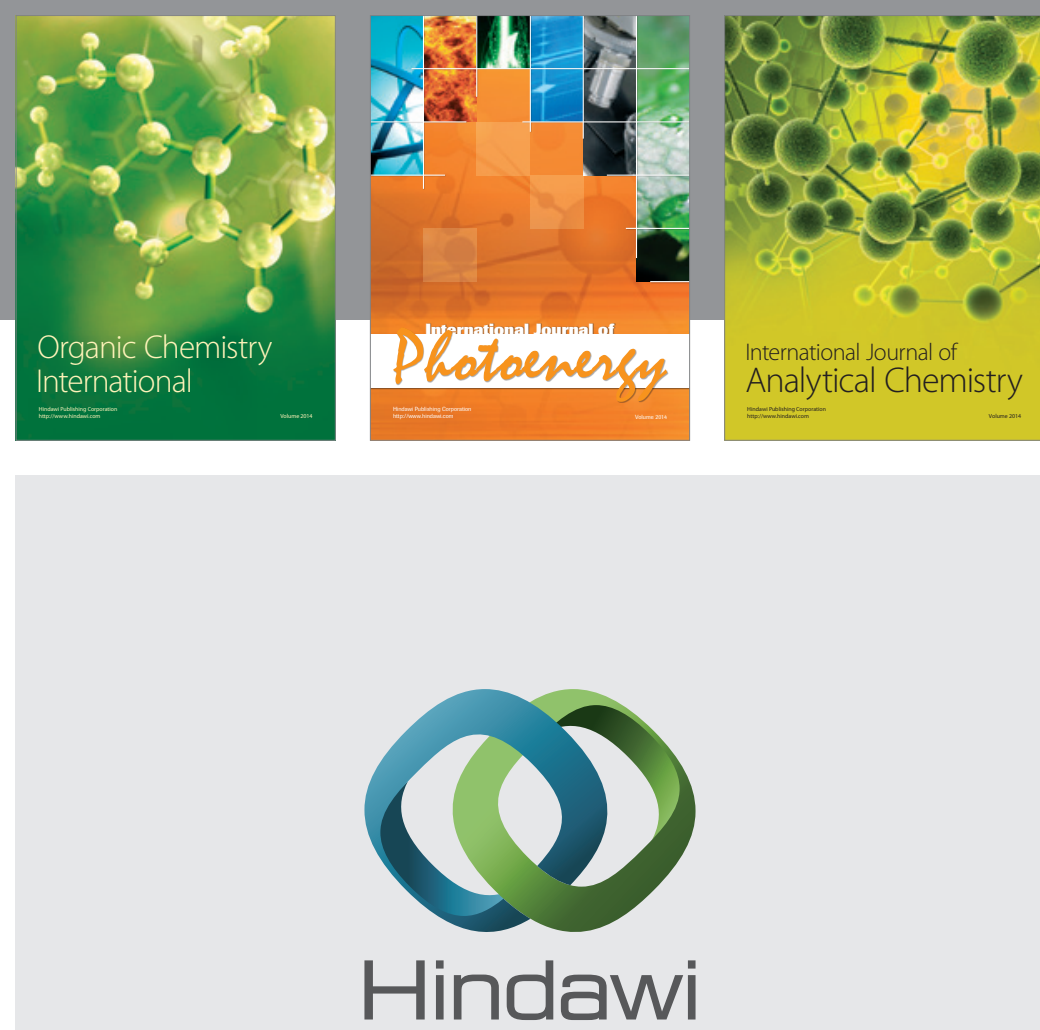

Submit your manuscripts at

http://www.hindawi.com
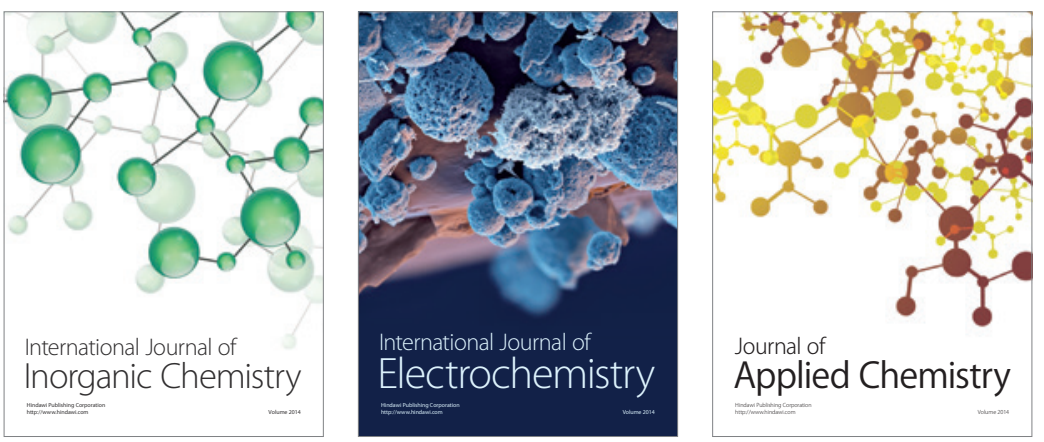

Journal of

Applied Chemistry
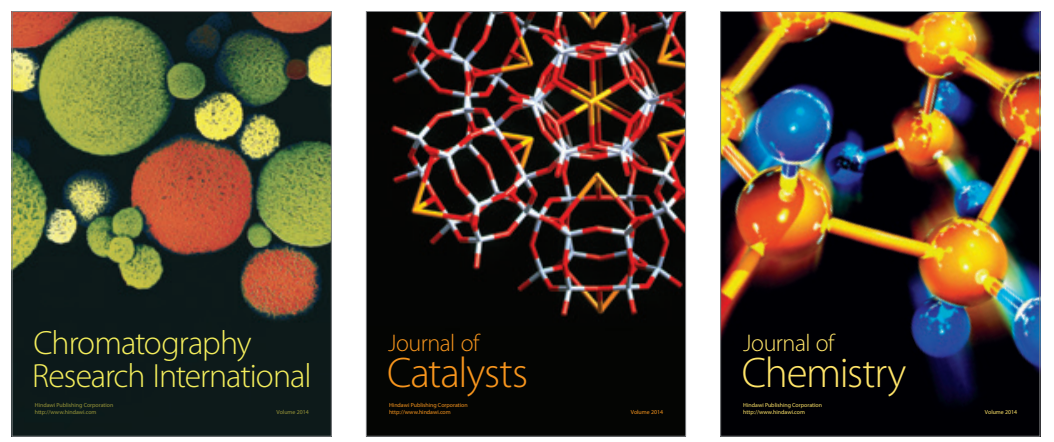
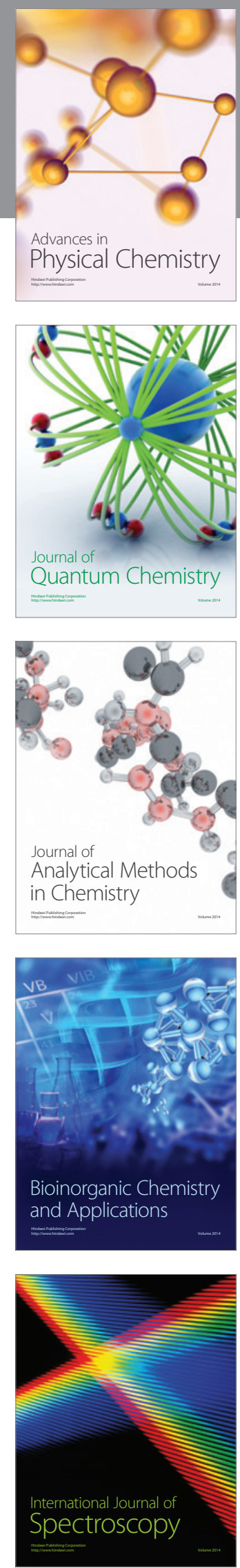